Article

\title{
Compositional Characteristics of Atmospheric Aerosols during a Consecutive High Concentration Episode in Seoul, Korea
}

\author{
Hee-Jung Ko ${ }^{1} \mathbb{D}$, Seung Joo Song ${ }^{2}$, Jeong Eun Kim ${ }^{1}$, Jung-Min Song ${ }^{3, *} \mathbb{C}$ and Joo Wan Cha ${ }^{4}$ \\ 1 Environmental Meteorology Research Division, National Institute of Meteorological Science, Seogwipo, \\ Jeju 63568, Korea; khj0614@korea.kr (H.-J.K.); narci76@korea.kr (J.E.K.) \\ 2 Emission Inventory Management Team, National Center for Fine Dust Information, Cheongju-si, \\ Chungcheongbuk-do 28166, Korea; sjtomato@korea.kr \\ 3 Department of Chemistry \& Cosmetics, Jeju National University, Jeju-si, Jeju 63243, Korea \\ 4 Applied Meteorology Research Division, National Institute of Meteorological Science, Jeju 63568, Korea; \\ jwcha@korea.kr \\ * Correspondence: sjm6990@gmail.com.; Tel.: +82-64-754-3540
}

Received: 8 January 2020; Accepted: 19 March 2020; Published: 22 March 2020

\begin{abstract}
This study focuses on the temporal variation in the compositional characteristics of atmospheric aerosols in Seoul, South Korea, during the consecutive high aerosol concentration episode from 30 December 2013 to 2 January 2014. The temporal variations in the observed physical, optical, and chemical properties show that there were three distinct episodes during the period: haze, mixed haze/Asian dust, and Asian dust episodes. For the haze period, the concentration of secondary inorganic aerosols increased and both secondary inorganic aerosols and calcium species exhibited simultaneously high concentrations during the mixed haze/Asian dust period. The neutralization factors by ammonia in the haze periods were higher as 1.03 than the other periods, meanwhile the neutralization contribution by calcium carbonate was relatively higher as 1.39 during the Asian dust episode. The backward trajectory analysis showed that concentrations of $\mathrm{SO}_{4}{ }^{2-}, \mathrm{NO}_{3}{ }^{-}$, and $\mathrm{NH}_{4}{ }^{+}$ were relatively high when air masses moved over East China. Principal component analysis showed that water-soluble components originated from soil dust/incineration, secondary aerosols/biomass burning, and road dust from the haze aerosol. For the mixed haze/Asian dust episode, the major source of aerosols was estimated to have originated from soil dust, pollutants from fossil fuel combustion, biomass burning, and sea-salt emissions. Furthermore, the main sources of ionic species in the Asian dust aerosols were estimated to be sea-salt/soil dust, secondary aerosols/coal combustion, and road dust.
\end{abstract}

Keywords: aerosol; sky radiometer; particle-into-liquid sampler; haze; Asian dust; principal component analysis

\section{Introduction}

Aerosol particles play important role in the ambient air related to air quality, urban and regional air pollution, visibility, global climate, biogeochemical cycles, human health, etc. [1,2]. Aerosols can offset regional greenhouse warming effects directly by scattering sunlight back into space and indirectly by enhancing cloud albedo, thereby cooling the climate [3]. However, aerosol components such as soot heat the atmosphere by absorbing sunlight and thereby augmenting the warming produced by the greenhouse effect $[3,4]$. Over polluted regions, long-range transport of mineral dust mixed with anthropogenic species could induce substantial changes in the optical and chemical properties of aerosols [3,5]. 
Research on the concentration, size, and chemical composition at the receptors is essential to elucidate the sources of aerosols and the processes associated with their formation [6]. Both natural and anthropogenic sources, such as road dust, vehicular emissions, secondary aerosols, sea-salt, and black carbon from oil burning, influence aerosol characteristics $[7,8]$. Source apportionment is an important approach for identifying and quantifying various sources of air pollutants $[9,10]$. The most common method is receptor modeling [11], which can provide a theoretical and mathematical framework for quantifying contributions from potential sources. The purpose of a receptor source apportionment model is to estimate the contributions of specific source types to pollutant levels in the atmosphere at a sampling (or receptor) site [12]. The contributions of each source are distinguished through differences in their physical and chemical properties [12]. Computer-generated source apportionment results must be interpreted by experts with knowledge about the site and the associated potential sources [12]. Principal component analysis is one of the most widely used multivariate statistical techniques in the atmospheric sciences [12,13].

In this study, data on the optical and chemical properties of atmospheric aerosols were collected and analyzed in real time at the Seoul Meteorological Station, South Korea during a consecutive high concentration episode from 30 December 2013 to 2 January 2014. This period was selected as a case study of dust and sand storm (DSS) events by working group-1 (WG1) of the Tripartite Environment Ministers Meeting among China, Japan, and Korea (TEMM) [14]. More specifically, the solar radiation properties and concentrations of the water-soluble ionic components of the ambient aerosols were analyzed to identify the possible sources of the main aerosol constituents.

\section{Method}

Seoul Meteorological Station $\left(37.57^{\circ} \mathrm{N}, 126.97^{\circ} \mathrm{E}\right)$ is situated in the Songwol-dong area located in the middle of Seoul, South Korea at a height of $85.5 \mathrm{~m}$. An intensive observation study of atmospheric aerosols was carried out during the high aerosol concentration episode from 30 December 2013 to 2 January 2014. Surface weather map charts and meteorological parameters, including wind speed, wind direction, humidity, and visibility, were continuously measured at this station by the Korean Meteorological Administration. The HYSPLIT 4.0 model developed at National Oceanic and Atmospheric Administration (NOAA) was used to estimate the upstream path of air flow during this period. The HYSPLIT simulations were run using the Unified Model-Global Data Assimilation and Prediction System (UM-GDAPS) with weather data from Korea Meteorological Administration (KMA) for $72 \mathrm{~h}$ before each episode at altitude of $500 \mathrm{~m}$ above ground level [15].

Direct and diffuse solar radiations were measured using a collocated sky radiometer (POM-02L, Prede Co. Ltd, Japan) at Seoul Meteorological Station.

The aerosol optical depth (AOD) and single scattering albedo (SSA) at five wavelengths (400, 500, 675,870 , and $1020 \mathrm{~nm}$ ) were retrieved using the SKYRAD.pack software (version 5.0) package [16]. The Ångström exponent (AE) was calculated as a log-linear fitting for the five wavelengths.

The $\mathrm{PM}_{10}$ (particle matter with an aerodynamic diameter of less than or equal to $10 \mu \mathrm{m}$ ), $\mathrm{PM}_{2.5}$, and $\mathrm{PM}_{1.0}$ concentrations were measured using the Environmental Dust Monitoring (EDM, \#180, GRIMM, Germany) system with 31 channels of different sizes at a flow rate of $1.2 \mathrm{~L} \mathrm{~min}^{-1}$ at Seoul Meteorological Station. The instrument is designed to measure the particle size distribution and particulate mass based on light scattering by individual aerosol particles in the ambient air.

Semi-continuous measurements of the ionic concentrations in $\mathrm{PM}_{10}$ aerosols were taken at $20 \mathrm{~min}$ intervals using a particle-into-liquid sampler (PILS, model ADI-2081, Metrohm, Switzerland) coupled to two ion chromatography systems (IC, model ICS-5000, Thermo Fisher Scientific, United States). The PILS nucleates aerosol particles to form water droplets by mixing a denuded aerosol stream with a supersaturated steam. The nucleated droplets are collected in a flowing liquid stream by inertial impaction. The liquid stream, which contains an internal Lithium bromide ( $\mathrm{LiBr}$ ) standard to determine dilution by condensed water vapor, is split into two streams. These are then injected into two ion chromatography systems every $20 \mathrm{~min}$ to analyze the ionic concentrations for the major water-soluble 
inorganic species $\left(\mathrm{Na}^{+}, \mathrm{NH}_{4}{ }^{+}, \mathrm{K}^{+}, \mathrm{Mg}^{2+}, \mathrm{Ca}^{2+}, \mathrm{SO}_{4}{ }^{2-}, \mathrm{NO}_{2}{ }^{-}, \mathrm{NO}_{3}{ }^{-}, \mathrm{Cl}^{-}\right)$. Eluent for the cationic analysis was $20 \mathrm{mM}$ methane sulfonic acid with a flow rate of $0.5 \mathrm{~mL} \mathrm{~min}^{-1}$ using CG12A/CS12A column and CSRS-ULTRA II suppressor. The analysis of anionic species was performed with an ion chromatograph equipped using AG19/AS19 column (13 mM KOH eluent) and ASRS-ULTRA II suppressor. The standard calibration curve for the analysis of cations and anions showed linearity with $\mathrm{R}^{2}=0.9999$ or better. During the analysis period and depending on the species, the limit of detection (LOD) for IC analyses of the ionic species ranged from 0.05 to $0.1 \mu \mathrm{g} \mathrm{m}^{-3}$.

\section{Results and Discussion}

\subsection{Meteorological Conditions and Mass Concentrations}

Surface weather maps for 29 December 2013 to 1 January 2014 are shown in Figure 1. The atmosphere around the Korean peninsula was stable due to the effect of high pressure from 29 December to the morning of 31 December (Figure 1a, Figure 2b). Haze was observed in Seoul on 30 and 31 December. On the afternoon of 31 December the Korean peninsula was affected by a low-pressure system over northeastern China. The $850 \mathrm{hPa}$ wind speed increased, and the wind direction changed from southwest to northwest after January 1, 2014. Asian dust was observed from 02:30 KST 1 January 2014, and the ratios of $\mathrm{PM}_{2.5}$ to $\mathrm{PM}_{10}$ were mainly below 0.5 after this time.

(a)

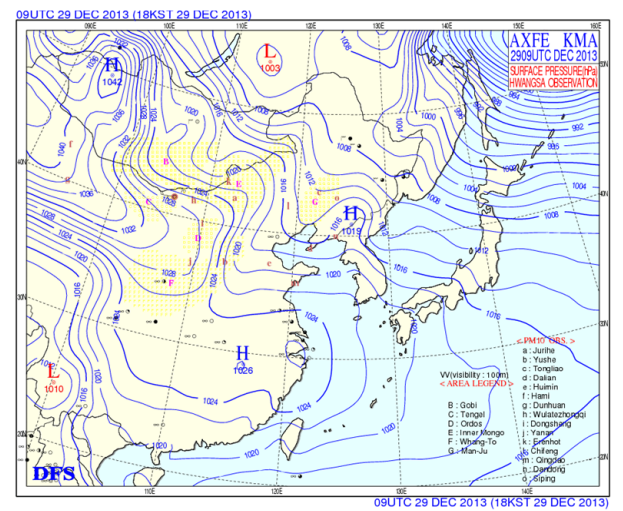

(c)

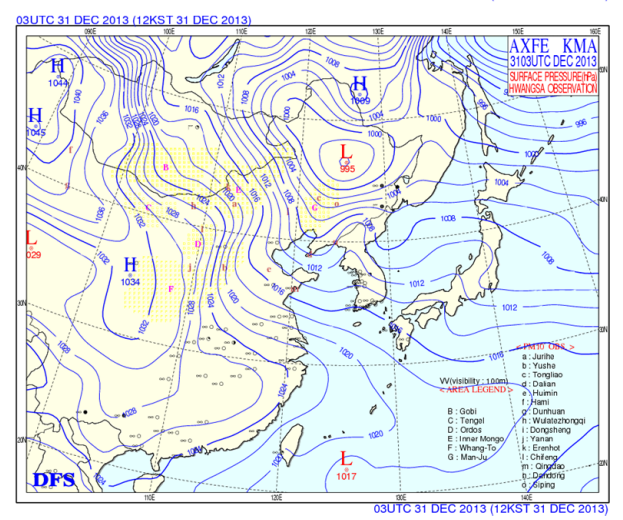

(b)

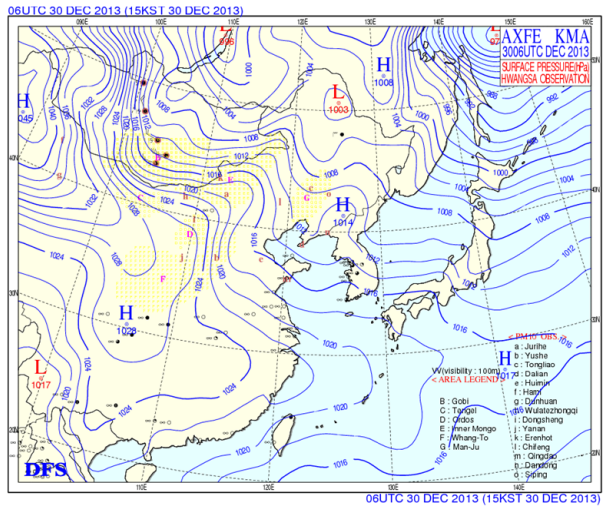

(d)

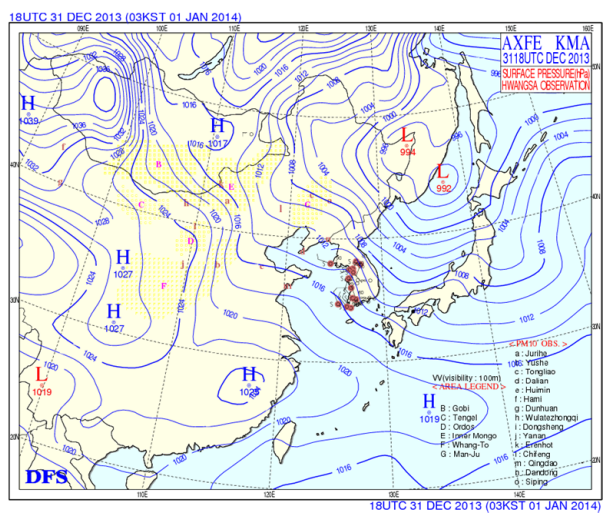

Figure 1. Surface weather chart for (a) 29 December 2013 at 18:00 KST, (b) 30 December 2013 at 15:00 KST, (c) 31 December 2013 at 12:00 KST, and (d) 1 January 2014 at 03:00 KST. 


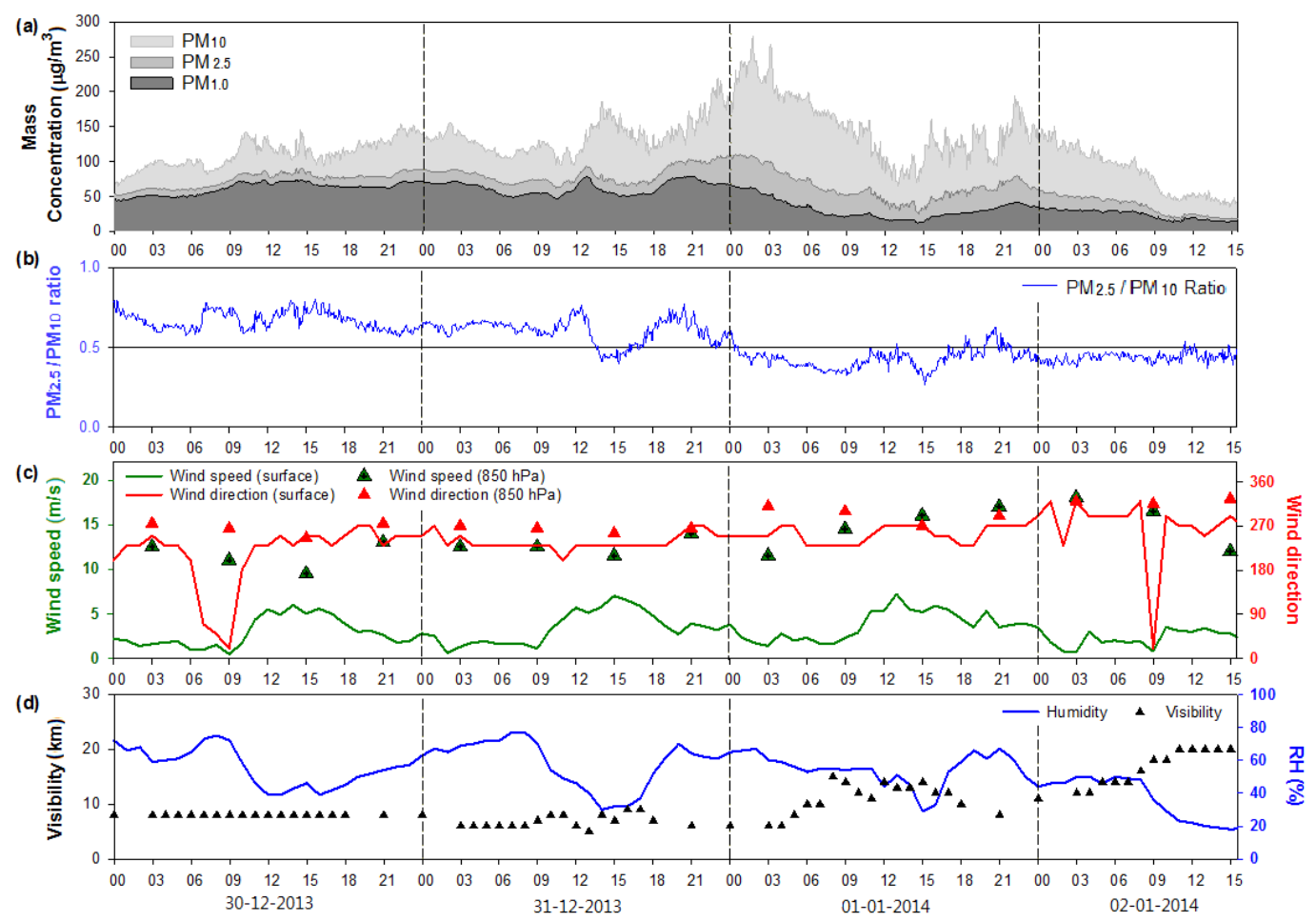

Figure 2. Time series of (a) $\mathrm{PM}_{10}, \mathrm{PM}_{2.5}$, and $\mathrm{PM}_{1.0}$ mass concentrations; (b) $\mathrm{PM}_{2.5} / \mathrm{PM}_{10}$ ratio; (c) wind direction and wind speed (-: surface (Seoul), $\triangle: 850 \mathrm{hPa}($ Osan)); and (d) humidity and visibility from 30 December 2013 to 2 January 2014.

Figure 2 presents the temporal variations of $\mathrm{PM}_{10}, \mathrm{PM}_{2.5}$, and $\mathrm{PM}_{1.0}$ mass concentrations; the ratio of $\mathrm{PM}_{2.5}$ to $\mathrm{PM}_{10}$; and the meteorological conditions (wind speed, wind direction, humidity, and visibility) from 30 December 2013 to 2 January 2014. From December 30 to the morning of 31 December, the ratio of $\mathrm{PM}_{2.5}$ to $\mathrm{PM}_{10}$ exceeded 0.6, thus indicating that fine particles were predominant. The maximum concentration of $\mathrm{PM}_{10}$ during this period was $156 \mu \mathrm{g} \mathrm{m}^{-3}$. After 12:00 KST on 31 December, the concentration began to increase again and reached the highest value of $279.7 \mu \mathrm{g} \mathrm{m}^{-3}$ between 00:00 - 03:00 KST 1 January (Figure 2a).

Figure 2c,d shows that the wind speed increased while humidity decreased from 09:00 KST on 31 December 2013. In addition, the mass concentration both $\mathrm{PM}_{10}$ and $\mathrm{PM}_{2.5}$ were increased, and the concentration ratio of $\mathrm{PM}_{2.5} / \mathrm{PM}_{10}$ showed a tendency to increase after 15:00 KST on 31 December Therefore, it was determined that the mass concentration of $\mathrm{PM}_{10}$ was increased relative to $\mathrm{PM}_{2.5}$ and $\mathrm{PM}_{1.0}$ after 09:00 KST on 31 December 2013.

\subsection{Aerosol Optical Properties}

Figure 3a shows the means of AOD $(500 \mathrm{~nm}), \mathrm{AE}$, and SSA $(500 \mathrm{~nm})$ retrieved from the sky radiometer data for 31 December and 1 January. There was no sky radiometer observation on 30 December due to clouds. The daily mean AOD was 0.57 on 31 December 2013, which was higher by $80 \%$ as compared to that on 1 January. The AE values were 1.03 and 0.48 on 31 December and 1 January, respectively, indicating that coarse particles dominated on 1 January. The average values for SSA were 0.90 and 0.93 for 31 December and 1 January, respectively. Aerosol types can be classified using AE and SSA, which determine the size of aerosols and distinguish absorbing/non-absorbing aerosols, respectively. Finer particles have a higher AE, and more absorbing aerosols have a lower SSA. Black carbon is a well-known absorbing aerosol, but dust particles also appeared to be solar absorbing aerosols [17]. Aerosol type classification for columnar aerosols was suggested by previous studies [18-20]. This study adopted one of these aerosol type classification criteria, suggested in Mielonen et al. [20]. Fine-mode aerosols are defined as having an AE greater than 1.2, while coarse-mode 
aerosols are defined as having an AE less than 0.8. Aerosols between these threshold values are classified as a "Mixture" mode. The SSA threshold of 0.95 is used to distinguish absorbing from non-absorbing aerosols. Values below 0.95 in the coarse mode indicate "Dust" and values above 0.95 indicate "Uncertain" SSA values below 0.95 in the fine mode indicate "black carbon (BC)," and values above 0.95 indicate "non-absorption (NA)" The dominant aerosol types on two days are shown in Figure $3 \mathrm{~b}$. The means of SSA for both days were similar, but SSAs on 1 January were more scattered (0.73-0.95) than on 31 December. All data on 31 December were in the "Mixture" category indicating that both coarse and fine particles exist, whereas "Dust" was most frequently detected on 1 January.
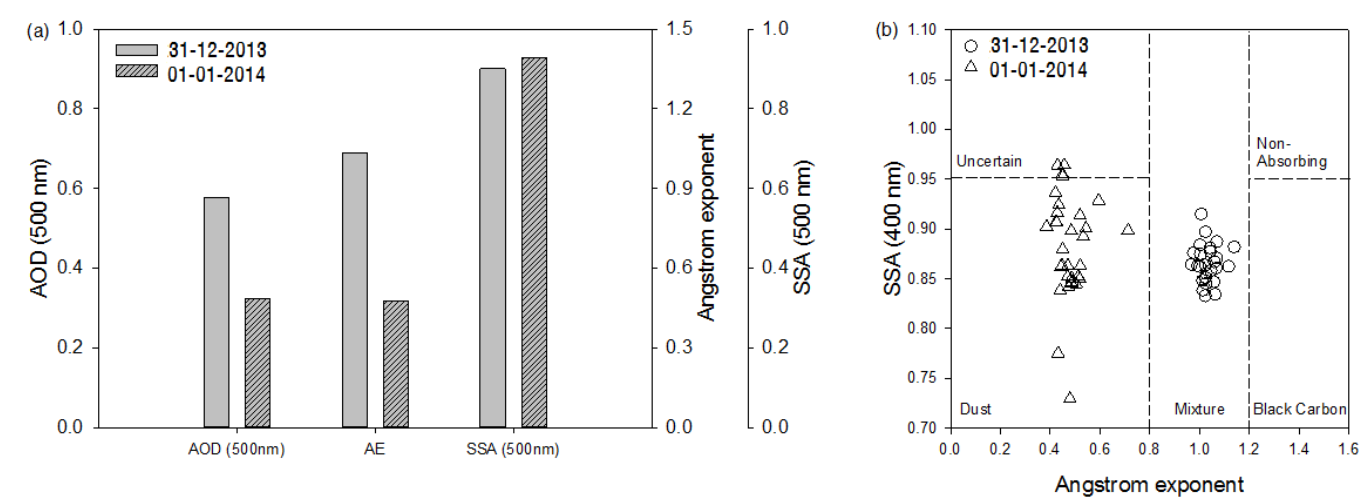

Figure 3. (a) Aerosol optical depth (500 nm), Ångström Exponent, and Single Scattering Albedo $(500 \mathrm{~nm})$ and (b) the frequency distribution of aerosol types from 31 December 2013 and 1 January 2014.

\subsection{Ionic Concentrations of Aerosols}

The concentrations of the major water-soluble ionic species in $\mathrm{PM}_{10}$ were analyzed semi-continuously using the PILS-IC system to examine the chemical characteristics of the aerosol particles. Time series variations in the concentrations of ionic species $\left(\mathrm{Na}^{+}, \mathrm{NH}_{4}{ }^{+}, \mathrm{K}^{+}, \mathrm{Mg}^{2+}, \mathrm{Ca}^{2+}\right.$, $\mathrm{SO}_{4}{ }^{2-}, \mathrm{NO}_{2}{ }^{-}, \mathrm{NO}_{3}{ }^{-}, \mathrm{Cl}^{-}$) are shown in Figure 4a. Here, the concentrations of calcium carbonate and magnesium carbonates were calculated as the soluble (sol) fractions of $\mathrm{Ca}$ and $\mathrm{Mg}$ and were added to the calculated $\mathrm{CO}_{3}{ }^{2-}$ concentrations [21]. The $\mathrm{CO}_{3}{ }^{2-}$ was calculated using Equation (1):

$$
\mathrm{CO}_{3}{ }^{2-}=2.5\left[\mathrm{Mg}_{\mathrm{sol}}\right]+1.5\left[\mathrm{Ca}_{\mathrm{sol}}\right]
$$

The concentrations of the ionic species were ordered as $\mathrm{NO}_{3}{ }^{-}\left(12.43 \mu \mathrm{g} \mathrm{m}^{-3}\right)>\mathrm{CO}_{3}{ }^{2-}\left(6.89 \mu \mathrm{g} \mathrm{m}^{-3}\right)$ $>\mathrm{SO}_{4}{ }^{2-}\left(6.82 \mu \mathrm{g} \mathrm{m}^{-3}\right)>\mathrm{NH}_{4}{ }^{+}\left(5.35 \mu \mathrm{g} \mathrm{m}^{-3}\right)>\mathrm{Ca}^{2+}\left(4.29 \mu \mathrm{g} \mathrm{m}^{-3}\right)>\mathrm{Cl}^{-}\left(2.49 \mu \mathrm{g} \mathrm{m}^{-3}\right)>\mathrm{Na}^{+}(1.78 \mu \mathrm{g}$ $\left.\mathrm{m}^{-3}\right)>\mathrm{K}^{+}\left(1.29 \mu \mathrm{g} \mathrm{m}^{-3}\right)>\mathrm{NO}_{2}^{-}\left(0.26 \mu \mathrm{g} \mathrm{m}^{-3}\right)>\mathrm{Mg}^{2+}\left(0.26 \mu \mathrm{g} \mathrm{m}^{-3}\right)$. The concentrations of $\mathrm{NO}_{3}^{-}$, $\mathrm{SO}_{4}{ }^{2-}, \mathrm{Ca}^{2+}$, and $\mathrm{NH}_{4}{ }^{+}$were $2.28-25.37,1.71-12.65,0.03-8.26$, and $0.03-11.67 \mu \mathrm{g} \mathrm{m}^{-3}$, respectively. In addition, the concentrations of $\mathrm{NO}_{3}{ }^{-}, \mathrm{SO}_{4}{ }^{2-}$, and $\mathrm{NH}_{4}{ }^{+}$were relatively high from 02:00 KST on 30 December to 08:00 KST on 31 December. The concentrations of $\mathrm{NO}_{3}{ }^{-}$and $\mathrm{CO}_{3}{ }^{2-}$ were high from 09:00 KST on 31 December to 08:00 KST on 1 January. The concentrations of $\mathrm{Ca}^{2+}$ and $\mathrm{CO}_{3}{ }^{2-}$ were high from 09:00 KST on 1 January to 10:00 KST on 2 January. Based on this analysis, the study period was divided into three episodes: the haze period (02:00 KST on 30 December to 08:00 KST on 31 December), the mixed haze/Asian dust period (09:00 KST on 31 December to 08:00 KST on 1 January), and the Asian dust period (09:00 KST on 1 January to 10:00 KST on 2 January). This chemical characteristic was similar to the $\mathrm{PM}_{10}$ mass concentration, the ratio of the $\mathrm{PM}_{2.5} / \mathrm{PM}_{10}$, and optical characteristics. Using these results, we investigated the chemical compositions, neutralization factors, and pollution sources of the three episodes.

The composition ratios of the ionic species in $\mathrm{PM}_{10}$ during the study period are shown in Figure $4 \mathrm{~b}$. The composition ratios of secondary inorganic aerosols $\left(\mathrm{NH}_{4}{ }^{+}, \mathrm{NO}_{3}{ }^{-}\right.$, and $\left.\mathrm{SO}_{4}{ }^{2-}\right)$, soil $\left(\mathrm{Ca}^{2+}\right.$ and $\mathrm{CO}_{3}{ }^{2-}$ ), sea-salt $\left(\mathrm{Na}^{+}, \mathrm{Cl}^{-}\right.$, and $\left.\mathrm{Mg}^{2+}\right)$, and other species in $\mathrm{PM}_{10}$ during the study periods were $55.7 \%$, $28.8 \%, 11.5 \%$, and $4.10 \%$, respectively. Their species ranges were $28.3-85.8 \%, 0.3-53.5 \%, 7.9-16.3 \%$, and 
0.9-12.6\%, respectively. The composition ratios of the secondary inorganic aerosol species were $80.2 \%$, $57.0 \%$, and $36.5 \%$, and those of the soil species were $7.9 \%, 28.1 \%$, and $44.6 \%$ of the total ionic species for the haze, mixed haze/Asian dust, and Asian dust episodes, respectively. Sea-salt species accounted for $9.9 \%, 10.8 \%$, and $13.2 \%$, while the others accounted for $1.9 \%, 4.2 \%$, and $5.6 \%$ of the haze, mixed haze/Asian dust, and Asian dust episodes, respectively. The composition ratios of secondary inorganic aerosol species were higher during the haze episode, whereas those of the soil and other species were higher during the Asian dust episode. In particular, $\mathrm{CO}_{3}{ }^{2-}$ was the most dominant anion, and $\mathrm{Ca}^{2+}$ and $\mathrm{Mg}^{2+}$ were major cations during the mixed haze/Asian dust and Asian dust episodes.

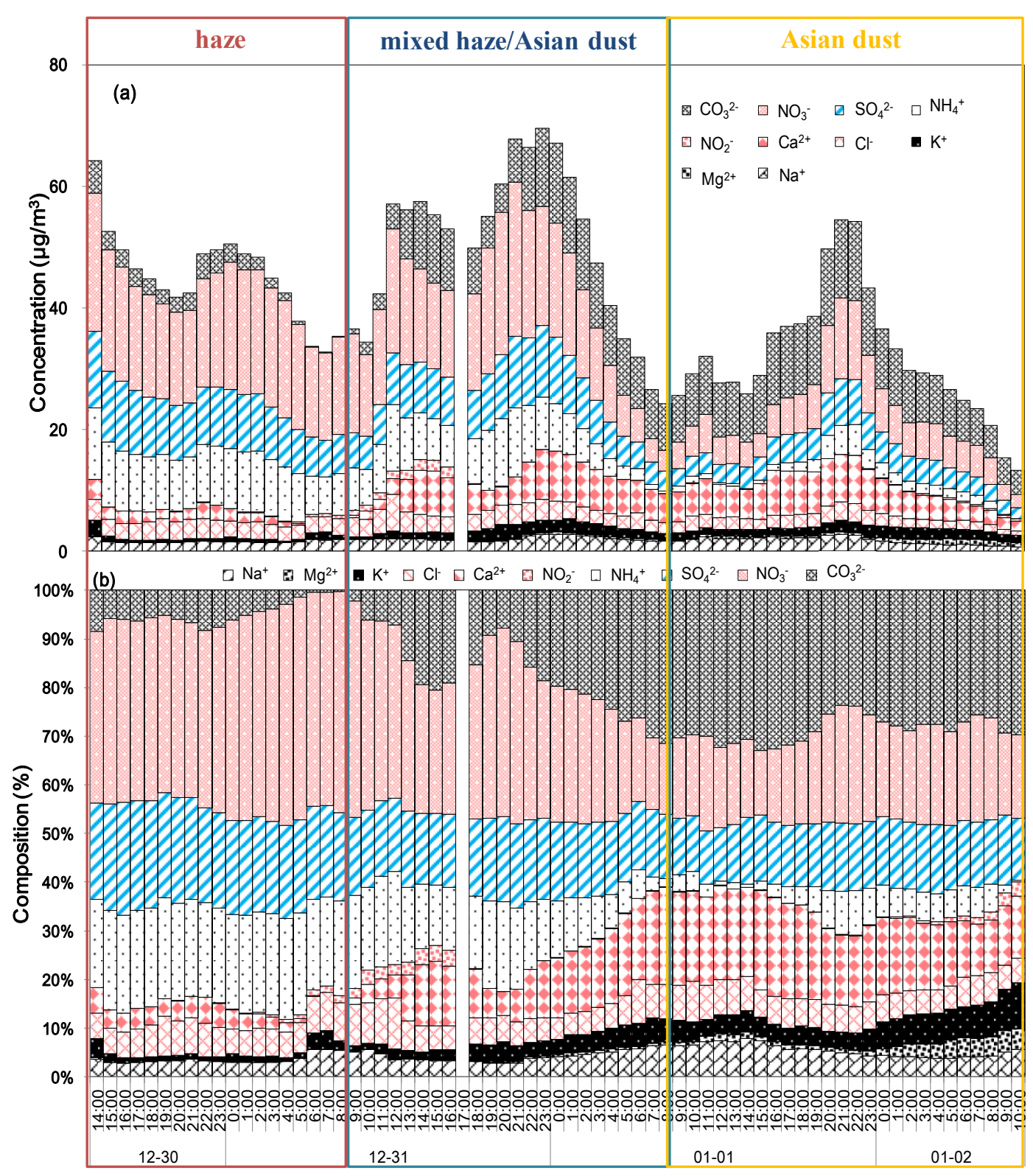

Figure 4. Time series of $1 \mathrm{~h}$ averaged (a) ionic concentrations and (b) their ionic compositions during the study period.

Figure 5 shows the $72 \mathrm{~h}$ air mass backward trajectories at a height of $500 \mathrm{~m}$ colored according to the concentration of the ionic component pollutants. The backward trajectories were similar for the haze and mixed haze/Asian dust episodes, while air masses for the Asian dust case seemed to move faster than those for the other cases. $\mathrm{NO}_{3}{ }^{-}, \mathrm{SO}_{4}{ }^{2-}, \mathrm{NH}_{4}{ }^{+}$, i.e., the anthropogenic pollutants, showed elevated concentrations when the trajectories passed over the industrialized area in East China. During 
the Asian dust episode, the air masses passed over Mongolia and Inner Mongolia, the major Asian Dust source regions, and $\mathrm{Ca}^{2+}$ mainly originating from soil dust showed higher concentrations.
species
(a) haze
(b) mixed haze/Asian
(c) Asian dust
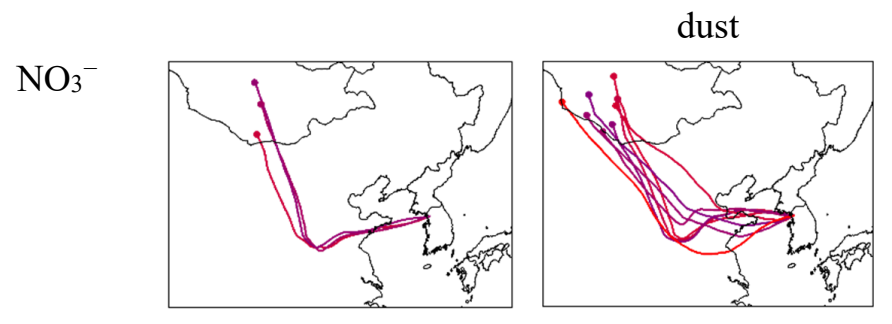

$\mathrm{SO}_{4}^{2-}$
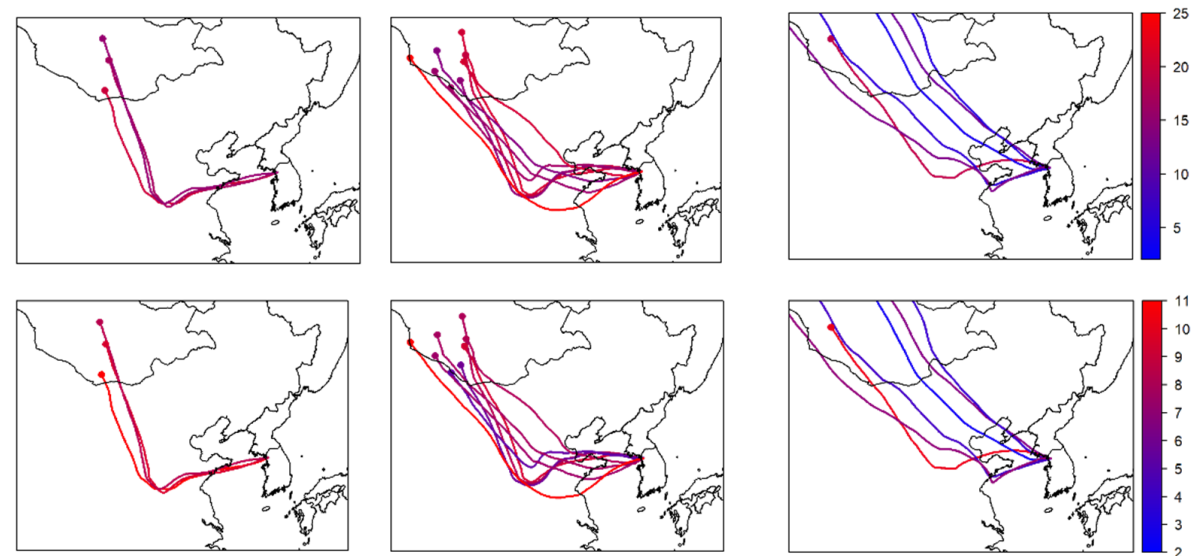

SO
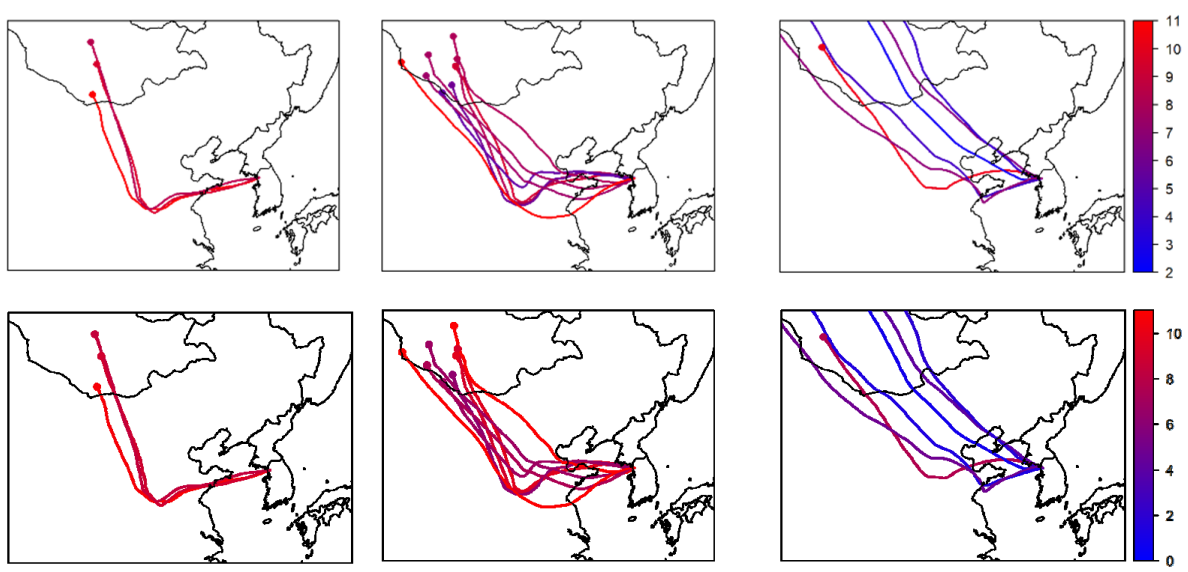

$\mathrm{NH}_{4}^{+}$
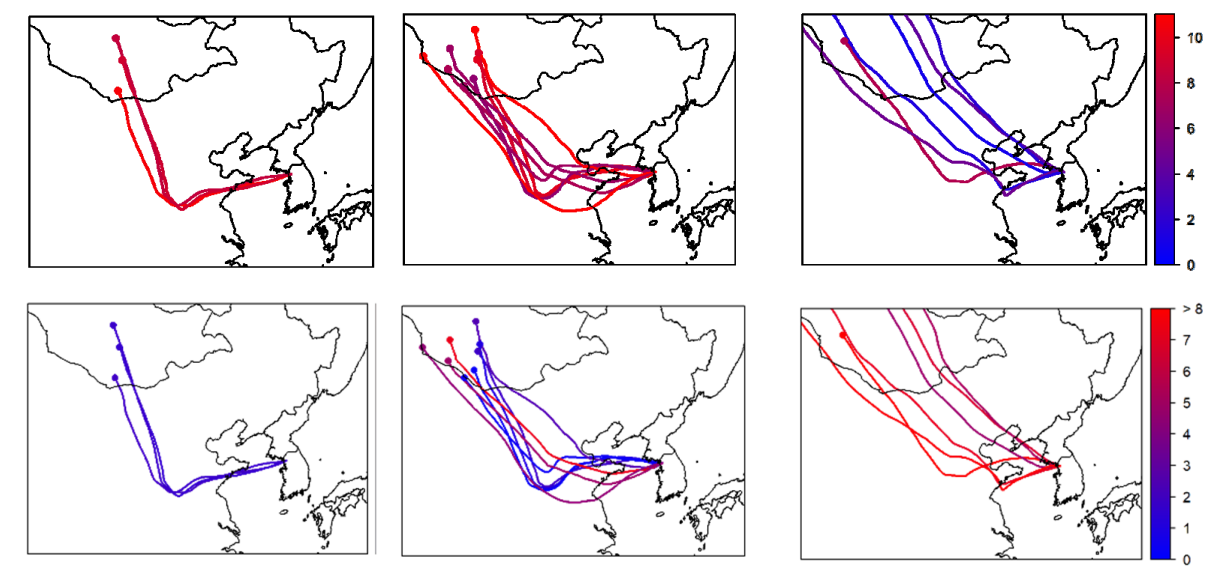

$\mathrm{Ca}^{2+}$

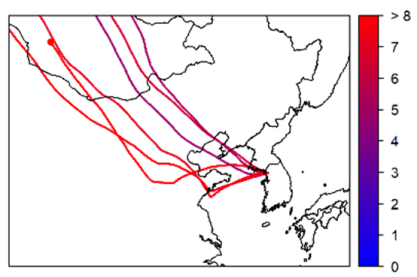

$\mathrm{PM}_{10}$
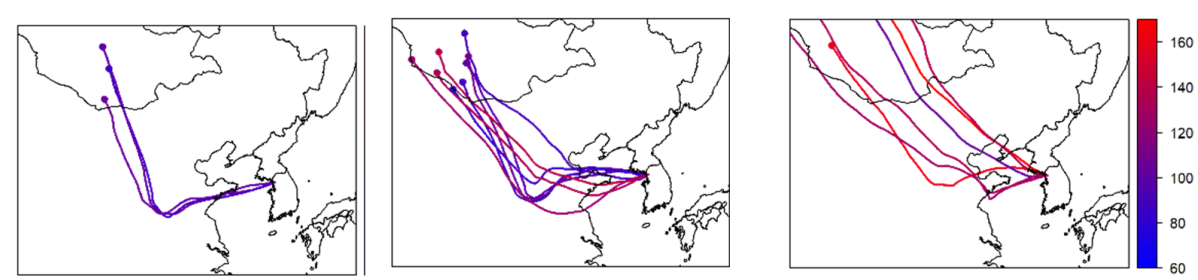

Figure 5. $72 \mathrm{~h}$ HYSPLIT backward trajectories at a height of $500 \mathrm{~m}$ arriving at the Seoul, colored according to the concentration of pollutants (in $\mu \mathrm{g} \mathrm{m}^{-3}$ ) for the (a) haze, (b) mixed haze/Asian dust, and (c) Asian dust episodes.

\subsection{Ammonium Salt Formation and Neutralization}

The secondary inorganic aerosol species, including $\mathrm{SO}_{4}{ }^{2-}, \mathrm{NO}_{3}{ }^{-}$, and $\mathrm{NH}_{4}{ }^{+}$, often exist in various forms, such as $\left(\mathrm{NH}_{4}\right)_{2} \mathrm{SO}_{4}, \mathrm{NH}_{4} \mathrm{HSO}_{4}$, and $\mathrm{NH}_{4} \mathrm{NO}_{3}$ [22]. The ratios for $\left(\mathrm{NH}_{4}\right)_{2} \mathrm{SO}_{4}$ and $\mathrm{NH}_{4} \mathrm{NO}_{3}$ that existed mainly in the ambient air could be calculated using Equations (2) and (3) [23].

$$
\begin{aligned}
& {\left[\text { nss-SO }{ }_{4}{ }^{2-}\right]_{\mathrm{eq}} /\left[\mathrm{NH}_{4}{ }^{+}\right]_{\mathrm{eq}}<1, \quad\left[\left(\mathrm{NH}_{4}\right)_{2} \mathrm{SO}_{4}\right]=1.38\left[\mathrm{nss}^{-\mathrm{SO}_{4}}{ }^{2-}\right]} \\
& {\left[\mathrm{nss}^{-\mathrm{SO}_{4}}{ }^{2-}\right]_{\mathrm{eq}} /\left[\mathrm{NH}_{4}{ }^{+}\right]_{\mathrm{eq}}>1, \quad\left[\left(\mathrm{NH}_{4}\right)_{2} \mathrm{SO}_{4}\right]=3.67\left[\mathrm{NH}_{4}{ }^{+}\right]} \\
& {\left[\mathrm{ex}-\mathrm{NH}_{4}{ }^{+}\right]=\left[\mathrm{NH}_{4}{ }^{+}\right]-0.27\left[\left(\mathrm{NH}_{4}\right)_{2} \mathrm{SO}_{4}\right], \quad\left[\mathrm{NH}_{4} \mathrm{NO}_{3}\right]=4.44\left[\mathrm{ex}-\mathrm{NH}_{4}{ }^{+}\right]}
\end{aligned}
$$


Figure 6 shows the concentrations of $\left(\mathrm{NH}_{4}\right)_{2} \mathrm{SO}_{4}$ and $\mathrm{NH}_{4} \mathrm{NO}_{3}$ estimated from the ionic analysis and the neutralization factors caused by the reaction between inorganic acids and bases, such as ammonia and calcium carbonate in $\mathrm{PM}_{10}$ aerosols. The estimated concentrations of $\left(\mathrm{NH}_{4}\right)_{2} \mathrm{SO}_{4}$ in Seoul were 12.6, 10.6, and $4.7 \mu \mathrm{g} \mathrm{m}^{-3}$, and those of $\mathrm{NH}_{4} \mathrm{NO}_{3}$ were 24.7, 16.6, and $1.5 \mu \mathrm{g} \mathrm{m}^{-3}$ for the haze, mixed haze/Asian dust, and Asian dust episodes, respectively, indicating relatively high concentrations in the haze period but lower concentrations in the Asian dust period. The estimated concentrations of $\left(\mathrm{NH}_{4}\right)_{2} \mathrm{SO}_{4}$ in $\mathrm{PM}_{10}$ at the Gosan, South Korea site were 22.9, 10.5, and $8.0 \mu \mathrm{g} \mathrm{m}^{-3}$, and those of $\mathrm{NH}_{4} \mathrm{NO}_{3}$ were 24.3, 0.1, and $0.09 \mu \mathrm{g} \mathrm{m}{ }^{-3}$ for the haze, mixed haze/Asian dust, and Asian dust, respectively [24].

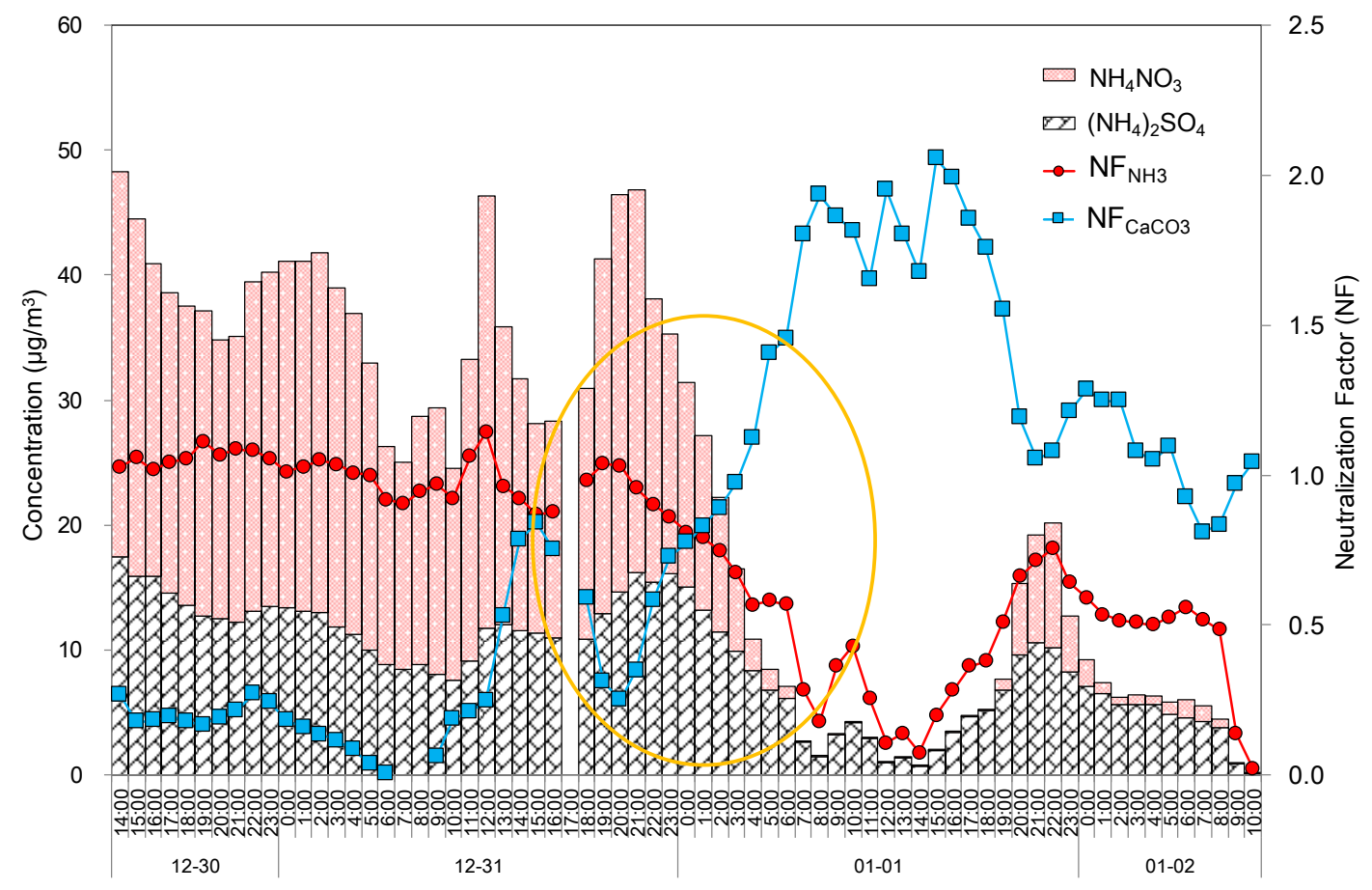

Figure 6. Time series variations of $1 \mathrm{~h}$ averaged estimated concentrations of $\left(\mathrm{NH}_{4}\right)_{2} \mathrm{SO}_{4}$ and $\mathrm{NH}_{4} \mathrm{NO}_{3}$ and neutralization factors by $\mathrm{NH}_{3}$ and $\mathrm{CaCO}_{3}$ during the high concentration episode.

Generally, the acid compounds in the air are neutralized by basic ammonia and carbonate compounds through the reactions between inorganic acids and base species, which are mostly ammonia or soil components, such as calcium carbonate and magnesium carbonate $[25,26]$. The neutralization factors are presented in Figure 6. The neutralization factors by ammonia were 1.03, 0.81, and 0.41 for the haze, mixed haze/Asian dust, and Asian dust episodes, respectively. Meanwhile, the neutralization factors by calcium carbonate were $0.16,0.77$, and 1.39, for haze, mixed haze/Asian dust, and Asian dust episodes, respectively.

It has been shown that the neutralization by ammonia was noticeably higher during the haze episode but decreased as the Asian dust episode began to occur. Conversely, the neutralization by calcium carbonate increased during the Asian dust episode. Interestingly, the neutralization by ammonia and calcium carbonate were reversed during the haze and mixed haze/Asian dust episodes. Therefore, it is thought that the concentrations of ammonium sulfate and ammonium nitrate would increase during the haze episode, while the soil-originated $\mathrm{CaCO}_{3}$ would increase during the Asian dust episode.

\subsection{Emission Sources of Ambient Aerosols}

Table 1 shows the correlation coefficients between the water-soluble ions in $\mathrm{PM}_{10}$ aerosols. In the results, $\mathrm{NH}_{4}{ }^{+}$was strongly correlated with $\mathrm{SO}_{4}{ }^{2-}$ in all haze $(\mathrm{r}=0.880)$, mixed haze/Asian dust 
$(\mathrm{r}=0.848)$, and Asian dust $(\mathrm{r}=0.911)$ episodes. Strong correlations were also found between $\mathrm{NH}_{4}{ }^{+}$ and $\mathrm{NO}_{3}{ }^{-}$in haze $(\mathrm{r}=0.783)$, mixed haze/Asian dust $(\mathrm{r}=0.971)$, and Asian dust $(\mathrm{r}=0.969) . \mathrm{Ca}^{2+}$ was strongly correlated with $\mathrm{CO}_{3}{ }^{2-}$ for all three episodes. These results suggest that $\left(\mathrm{NH}_{4}\right)_{2} \mathrm{SO}_{4}, \mathrm{NH}_{4} \mathrm{HSO}_{4}$, $\mathrm{NH}_{4} \mathrm{NO}_{3}$, and $\mathrm{CaCO}_{3}$ were the major chemical fractions in all three episodes.

Table 1. Correlation between the ionic species during the (a) haze, (b) mixed haze/Asian dust, and (c) Asian dust episodes.

\begin{tabular}{|c|c|c|c|c|c|c|c|c|c|c|}
\hline \multicolumn{11}{|c|}{ (a) Haze } \\
\hline Species & $\mathrm{Na}^{+}$ & $\mathrm{NH}_{4}^{+}$ & $\mathrm{K}^{+}$ & $\mathrm{Mg}^{2+}$ & $\mathrm{Ca}^{2+}$ & $\mathrm{Cl}^{-}$ & $\mathrm{NO}_{2}^{-}$ & $\mathrm{NO}_{3}^{-}$ & $\mathrm{SO}_{4}^{2-}$ & $\mathrm{CO}_{3}{ }^{2-}$ \\
\hline $\mathrm{Na}^{+}$ & 1.000 & & & & & & & & & \\
\hline $\mathrm{NH}_{4}{ }^{+}$ & 0.268 & 1.000 & & & & & & & & \\
\hline $\mathrm{K}^{+}$ & 0.471 & 0.737 & 1.000 & & & & & & & \\
\hline $\mathrm{Mg}^{2+}$ & 0.863 & 0.441 & 0.530 & 1.000 & & & & & & \\
\hline $\mathrm{Ca}^{2+}$ & 0.450 & 0.645 & 0.404 & 0.631 & 1.000 & & & & & \\
\hline $\mathrm{Cl}^{-}$ & 0.276 & 0.200 & 0.062 & 0.158 & 0.543 & 1.000 & & & & \\
\hline $\mathrm{NO}_{2}^{-}$ & -0.232 & -0.514 & -0.302 & -0.334 & -0.827 & -0.683 & 1.000 & & & \\
\hline $\mathrm{NO}_{3}^{-}$ & 0.142 & 0.783 & 0.632 & 0.351 & 0.231 & -0.352 & 0.056 & 1.000 & & \\
\hline $\mathrm{SO}_{4}^{2-}$ & 0.342 & 0.880 & 0.650 & 0.486 & 0.773 & 0.358 & -0.773 & 0.470 & 1.000 & \\
\hline $\mathrm{CO}_{3}{ }^{2-}$ & 0.473 & 0.647 & 0.415 & 0.654 & 1.000 & 0.536 & -0.819 & 0.239 & 0.773 & 1.000 \\
\hline \multicolumn{11}{|c|}{ (b) Mixed haze/Asian dust } \\
\hline Species & $\mathrm{Na}^{+}$ & $\mathrm{NH}_{4}^{+}$ & $\mathrm{K}^{+}$ & $\mathrm{Mg}^{2+}$ & $\mathrm{Ca}^{2+}$ & $\mathrm{Cl}^{-}$ & $\mathrm{NO}_{2}^{-}$ & $\mathrm{NO}_{3}^{-}$ & $\mathrm{SO}_{4}^{2-}$ & $\mathrm{CO}_{3}{ }^{2-}$ \\
\hline $\mathrm{Na}^{+}$ & 1.000 & & & & & & & & & \\
\hline $\mathrm{NH}_{4}{ }^{+}$ & 0.071 & 1.000 & & & & & & & & \\
\hline $\mathrm{K}^{+}$ & 0.439 & 0.107 & 1.000 & & & & & & & \\
\hline $\mathrm{Mg}^{2+}$ & 0.777 & -0.314 & 0.663 & 1.000 & & & & & & \\
\hline $\mathrm{Ca}^{2+}$ & 0.609 & -0.223 & 0.526 & 0.838 & 1.000 & & & & & \\
\hline $\mathrm{Cl}^{-}$ & 0.117 & 0.700 & -0.077 & -0.368 & -0.321 & 1.000 & & & & \\
\hline $\mathrm{NO}_{2}^{-}$ & -0.158 & 0.188 & -0.536 & -0.440 & -0.069 & 0.324 & 1.000 & & & \\
\hline $\mathrm{NO}_{3}^{-}$ & 0.212 & 0.971 & 0.260 & -0.144 & -0.131 & 0.605 & 0.053 & 1.000 & & \\
\hline $\mathrm{SO}_{4}^{2-}$ & 0.415 & 0.848 & 0.436 & 0.190 & 0.254 & 0.427 & -0.069 & 0.904 & 1.000 & \\
\hline $\mathrm{CO}_{3}^{2-}$ & 0.626 & -0.231 & 0.540 & 0.857 & 0.999 & -0.327 & -0.094 & -0.133 & 0.252 & 1.000 \\
\hline \multicolumn{11}{|c|}{ (c) Asian dust } \\
\hline Species & $\mathrm{Na}^{+}$ & $\mathrm{NH}_{4}^{+}$ & $\mathrm{K}^{+}$ & $\mathrm{Mg}^{2+}$ & $\mathrm{Ca}^{2+}$ & $\mathrm{Cl}^{-}$ & $\mathrm{NO}_{2}^{-}$ & $\mathrm{NO}_{3}{ }^{-}$ & $\mathrm{SO}_{4}{ }^{2-}$ & $\mathrm{CO}_{3}{ }^{2-}$ \\
\hline $\mathrm{Na}^{+}$ & 1.000 & & & & & & & & & \\
\hline $\mathrm{NH}_{4}^{+}$ & 0.538 & 1.000 & & & & & & & & \\
\hline $\mathrm{K}^{+}$ & -0.063 & 0.702 & 1.000 & & & & & & & \\
\hline $\mathrm{Mg}^{2+}$ & -0.785 & -0.098 & 0.419 & 1.000 & & & & & & \\
\hline $\mathrm{Ca}^{2+}$ & 0.947 & 0.573 & 0.100 & -0.744 & 1.000 & & & & & \\
\hline $\mathrm{Cl}^{-}$ & 0.901 & 0.743 & 0.203 & -0.644 & 0.888 & 1.000 & & & & \\
\hline $\mathrm{NO}_{2}^{-}$ & -0.844 & -0.284 & 0.116 & 0.764 & -0.871 & -0.753 & 1.000 & & & \\
\hline $\mathrm{NO}_{3}^{-}$ & 0.695 & 0.969 & 0.579 & -0.258 & 0.709 & 0.848 & -0.438 & 1.000 & & \\
\hline $\mathrm{SO}_{4}{ }^{2-}$ & 0.760 & 0.911 & 0.564 & -0.347 & 0.824 & 0.849 & -0.556 & 0.955 & 1.000 & \\
\hline $\mathrm{CO}_{3}^{2-}$ & 0.912 & 0.649 & 0.226 & -0.618 & 0.985 & 0.879 & -0.828 & 0.768 & 0.880 & 1.000 \\
\hline
\end{tabular}

Principal component analysis (PCA) was applied to estimate the major emission sources of aerosol components [27]. PCA is the most common multivariate statistical method applied in environmental studies. The Statistical Package for the Social Sciences (SPSS) software (version 18.0) was used for the multivariate analysis. We applied PCA for the water-soluble ions analyzed during the episodes for source attribution. The varimax rotated factors of the loading matrix are presented in Table 2. 
Table 2. Principal component analysis results for water-soluble species during the haze, mixed haze/Asian dust, and Asian dust episodes, with loading $>0.5$ in bold. The analysis used a varimax rotation with Kaiser normalization.

\begin{tabular}{|c|c|c|c|c|c|c|c|c|c|c|}
\hline \multirow{2}{*}{ Species } & \multicolumn{3}{|c|}{ Haze } & \multicolumn{4}{|c|}{ Mixed haze/Asian Dust } & \multicolumn{3}{|c|}{ Asian Dust } \\
\hline & PC 1 & PC 2 & PC 3 & PC 1 & PC 2 & PC 3 & PC 4 & PC 1 & PC 2 & PC 3 \\
\hline $\mathrm{Na}^{+}$ & 0.171 & & 0.951 & 0.702 & 0.155 & 0.166 & 0.624 & 0.830 & 0.450 & \\
\hline $\mathrm{NH}_{4}^{+}$ & 0.429 & 0.875 & 0.100 & & 0.973 & & & 0.186 & 0.963 & 0.154 \\
\hline $\mathrm{K}^{+}$ & 0.145 & 0.752 & 0.380 & 0.531 & 0.302 & 0.651 & & & 0.649 & 0.712 \\
\hline $\mathrm{Mg}^{2+}$ & 0.238 & 0.301 & 0.889 & 0.866 & & 0.421 & 0.178 & & & 0.511 \\
\hline $\mathrm{Ca}^{2+}$ & 0.825 & 0.323 & 0.346 & 0.985 & & & & 0.888 & 0.437 & \\
\hline $\mathrm{Cl}^{-}$ & 0.823 & & 0.113 & & 0.602 & & 0.586 & 0.682 & 0.669 & \\
\hline \multicolumn{11}{|l|}{$\mathrm{NO}_{2}^{-}$} \\
\hline $\mathrm{NO}_{3}^{-}$ & & 0.941 & 0.105 & & 0.978 & & 0.105 & 0.350 & 0.929 & \\
\hline $\mathrm{SO}_{4}{ }^{2-}$ & 0.672 & 0.659 & 0.148 & 0.295 & 0.928 & 0.120 & & 0.519 & 0.824 & 0.176 \\
\hline $\mathrm{CO}_{3}^{2-}$ & 0.813 & 0.326 & 0.372 & 0.987 & & & & 0.840 & 0.507 & \\
\hline Eigenvalue & 3.7 & 3.1 & 2.2 & 3.7 & 3.3 & 1.7 & 0.8 & 4.7 & 4.0 & 0.9 \\
\hline Variance (\%) & 36.9 & 30.5 & 21.6 & 36.8 & 32.7 & 16.6 & 8.0 & 46.7 & 40.0 & 9.4 \\
\hline Cumulative (\%) & 36.9 & 67.5 & 89.0 & 36.8 & 69.6 & 86.2 & 94.2 & 46.7 & 86.7 & 96.2 \\
\hline
\end{tabular}

In the haze episode, the first three principal components with eigenvalues greater than one were extracted; they accounted for $89.0 \%$ of the total variance. The first principal component (PC1), which explained $36.9 \%$ of the total variance with an eigenvalue of 3.7 was mostly dependent on $\mathrm{Ca}^{2+}, \mathrm{Cl}^{-}$, $\mathrm{SO}_{4}{ }^{2-}$, and $\mathrm{CO}_{3}{ }^{2-}$. The $\mathrm{Ca}^{2+}$ and $\mathrm{CO}_{3}{ }^{2-}$ species are considered to be soil dust sources [28], while $\mathrm{SO}_{4}{ }^{2-}$ and $\mathrm{Cl}^{-}$are typically produced by waste incinerators [29]. This indicates that $\mathrm{PC} 1$ is associated with soil dust and emissions from waste incinerators. The second principal component, PC2 accounted for $30.5 \%$ of the total variance and showed high loadings for $\mathrm{NH}_{4}{ }^{+}, \mathrm{SO}_{4}{ }^{2-}, \mathrm{NO}_{3}{ }^{-}$, and $\mathrm{K}^{+}$. Because $\mathrm{K}^{+}$is regarded as a tracer for biomass burning [30], PC2 can be associated with secondary aerosols mixed with biomass-burning aerosols [31]. $\mathrm{SO}_{4}{ }^{2-}$ showed a significant loading on both PC1 and PC2 indicating composite sources. Finally, PC3 explained 21.6\% of the total variance, which was dominated by $\mathrm{Na}^{+}$and $\mathrm{Mg}^{2+}$. A strong correlation between $\mathrm{Na}^{+}$and $\mathrm{Mg}^{2+}$ indicates that $\mathrm{Na}^{+}$and $\mathrm{Mg}^{2+}$ had the same origin Table 1a. Thus, the major sources of PC 3 were natural minerals characteristics (Figure 7a) [32].

In the mixed haze/Asian dust episode, four principal components were identified and accounted for $94.2 \%$ of the total variance. PC1, accounting for $36.8 \%$ of the total variance was heavily loaded by $\mathrm{Na}^{+}, \mathrm{Mg}^{2+}, \mathrm{Ca}^{2+}$, and $\mathrm{CO}_{3}{ }^{2-}$, with loadings of $0.702,0.866,0.985$, and 0.987 , respectively. $\mathrm{Mg}^{2+}$, $\mathrm{Ca}^{2+}$, and $\mathrm{CO}_{3}{ }^{2-}$ are regarded as tracers for soil dust sources from natural and a variety of crustal minerals [33]. The high correlation between $\mathrm{Na}^{+}$and $\mathrm{Mg}^{2+}(\mathrm{r}=0.777)$ indicates that $\mathrm{Na}^{+}$and $\mathrm{Mg}^{2+}$ share the same origin Table 1b. PC2 showed high loadings of the three secondary ions as well as $\mathrm{Cl}^{-}$ indicating that the secondary pollutants originated from fossil fuel combustion and other anthropogenic sources [31]. The loading of $\mathrm{K}^{+}$on PC3 (16.6\% of the total variance) mainly originated from biomass burning. PC4, which explained another $8.0 \%$ of the total variance grouped $\mathrm{Na}^{+}$and $\mathrm{Cl}^{-}$and appears to represent the sea-salt source (Figure $7 \mathrm{~b}$ ) [34].

Three principal components that explained $96.2 \%$ of the total variance were identified in the Asian dust episode. $\mathrm{PC} 1$, with $46.7 \%$ of the total variance, was loaded with $\mathrm{Na}^{+}, \mathrm{Ca}^{2+}, \mathrm{Cl}^{-}$, and $\mathrm{CO}_{3}{ }^{2-}$, with values of $0.830,0.888,0.682$, and 0.840 , respectively, indicating the presence of a mixture of sea-salt aerosols and soil dust. PC2, accounting for $40.0 \%$ of the variance was mainly affected by $\mathrm{NH}_{4}{ }^{+}(0.963)$, $\mathrm{K}^{+}$(0.649), $\mathrm{Cl}^{-}$(0.669), $\mathrm{NO}_{3}{ }^{-}(0.929)$, and $\mathrm{SO}_{4}{ }^{2-}$ (0.824). $\mathrm{NO}_{3}{ }^{-}, \mathrm{SO}_{4}{ }^{2-}$, and $\mathrm{NH}_{4}{ }^{+}$are the typical tracers of secondary origins, and $\mathrm{Cl}^{-}$and $\mathrm{K}^{+}$are emitted mainly from coal combustion and biomass burning [33]. PC3 accounted for $9.4 \%$ of the total variance and was strongly loaded with $\mathrm{K}^{+}$and $\mathrm{Mg}^{2+}$. These are regarded as tracers for crustal and construction dusts (Figure 7c). 


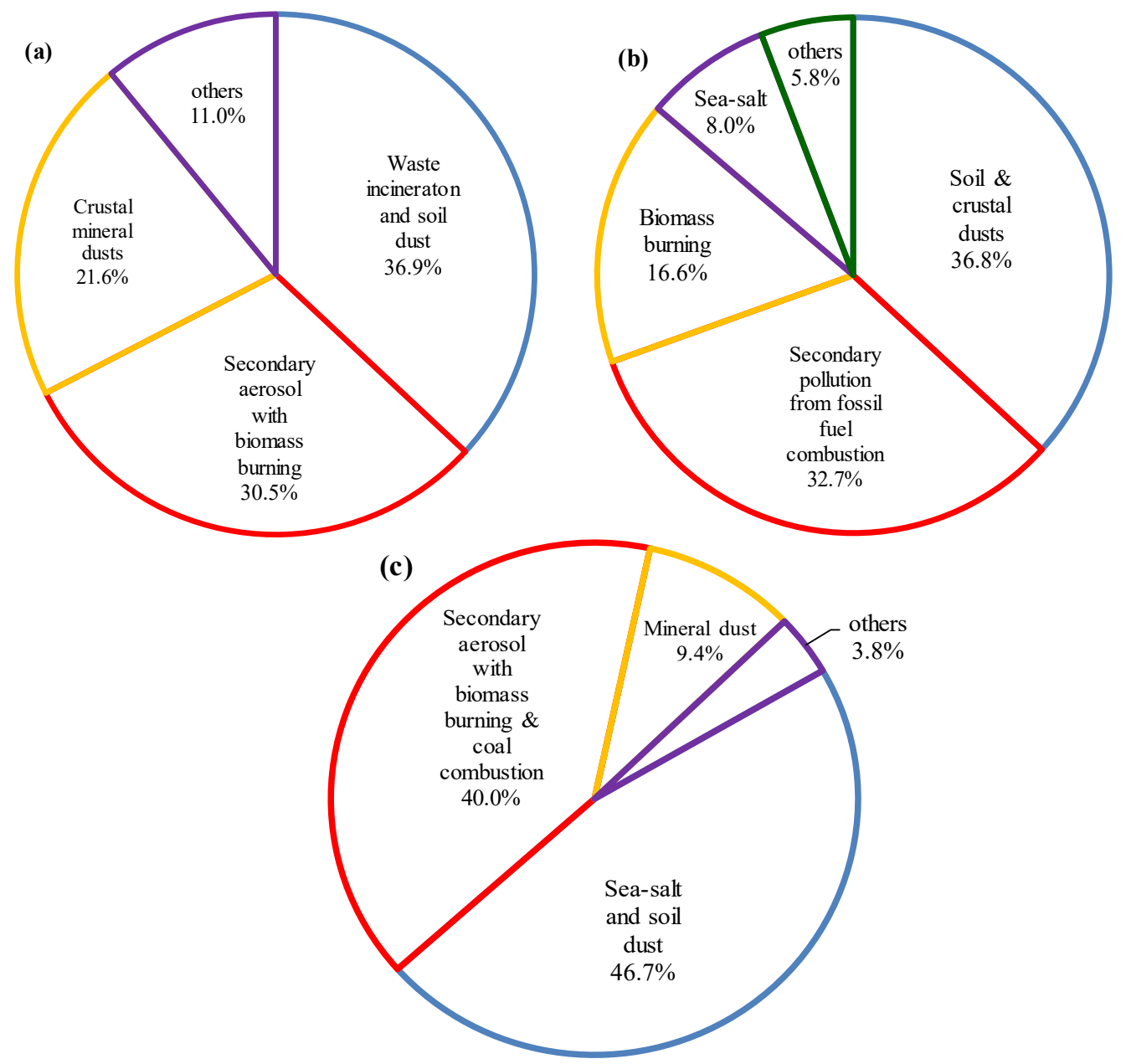

Figure 7. Source apportionments of water-soluble species in each episode: (a) haze, (b) mixed haze/Asian dust, and (c) Asian dust.

\section{Conclusions}

Through optical analyses using the sky radiometer, aerosol types were classified as "Mixture" and "Dust" particles for 31 December 2013 and 1 January 2014, respectively. The secondary inorganic aerosol species $\left(\mathrm{NH}_{4}{ }^{+}, \mathrm{NO}_{3}{ }^{-}\right.$, and $\left.\mathrm{SO}_{4}{ }^{2-}\right)$ during the haze episode had relatively higher concentrations $(80.2 \%)$ as compared to the other episodes. In addition, the composition ratios of soil $\left(\mathrm{Ca}^{2+}\right.$ and $\left.\mathrm{CO}_{3}{ }^{2-}\right)$ were 3.6 and 5.6 times increased in both the mixed haze/Asian dust and Asian dust episodes, respectively. The $\mathrm{NH}_{4} \mathrm{NO}_{3}$ content was higher than $\left(\mathrm{NH}_{4}\right)_{2} \mathrm{SO}_{4}$ during the haze, but it was relatively low during the Asian dust episode. Comparing the high aerosol concentration episodes, the neutralization by ammonia was noticeably higher during the haze episode, and calcium carbonate was more prominent during the Asian dust episode. The backward trajectories analysis indicated that the concentrations of the secondary inorganic aerosol species $\left(\mathrm{NH}_{4}{ }^{+}, \mathrm{NO}_{3}{ }^{-}\right.$, and $\left.\mathrm{SO}_{4}{ }^{2-}\right)$ were higher when the air masses moved over the industrialized area in East China. However, when the air mass was transported over Mongolia and Inner Mongolia during the Asian dust episode, the concentration of $\mathrm{Ca}^{2+}$ species was relatively higher. The neutralization factors of ammonia were $1.03,0.81,0.41$, respectively, for the haze, mixed haze/Asian dust, and Asian dust episodes. Moreover, the neutralization factors of calcium carbonate were $0.16,0.77,1.39$, respectively. Based on PCA, the haze episode compositions might be influenced by a mixture of soil dust and emissions from waste incinerators, a mixture of secondary aerosols and biomass burning, and crustal mineral dust. The compositions of the mixed haze/Asian dust period were most affected by a mixture of soil and crustal dusts, followed by secondary pollutants from fuel combustion, biomass burning, and sea-salt emissions. Moreover, a mixture of sea-salts and 
soil dust, a mixture of secondary aerosols with biomass burning and coal combustion, and mineral dust were the potential sources in the Asian dust episode.

Author Contributions: Conceptualization, H.-J.K. and J.-M.S.; methodology, H.-J.K., S.J.S., and J.E.K.; software, S.J.S.; validation, H.-J.K. and J.-M.S.; formal analysis, H.-J.K. and S.J.S.; investigation, J.W.C.; writing-original draft preparation, H.-J.K. and J.-M.S.; writing—review and editing, H.-J.K., S.J.S., J.E.K., and J.M.S. All authors have read and agreed to the published version of the manuscript.

Funding: This work was funded by the Korea Meteorological Administration Research and Development Program "Development of Asian Dust and Haze Monitoring and Prediction Technology" under Grant (1365003013).

Acknowledgments: The authors would like to thank technical and scientific staff members of the Seoul Meteorological Station and collocated Seoul Hwangsa Monitoring Centre and for their efforts to collect meteorological and aerosol data.

Conflicts of Interest: The authors declare no conflict of interest.

\section{References}

1. Heal, M.R.; Kumar, P.; Harrison, R.M. Particles, air quality, policy and health. Chem. Soc. Rev. 2012, 41, 6606-6630. [CrossRef]

2. Jiang, J.; Zhou, W.; Cheng, Z.; Wang, S.; He, K.; Hao, J. Particulate matter distributions in China during a winter period with frequent pollution episodes (January 2013). Aerosol Air Qual. Res. 2015, 15, 494-503. [CrossRef]

3. Gautam, R.; Hsu, N.C.; Lau, K.M. Premonsoon aerosol characterization and radiative effects over the Indo-Gangetic plains: Implications for regional climate warming. J. Geophys. Res. 2010, 115, D17208. [CrossRef]

4. Jacobson, M.Z. Strong radiative heating due to mixing state of black carbon on atmospheric aerosols. Nature. 2001, 409, 695-697. [CrossRef]

5. Seinfeld, J.H.; Carmichael, G.R.; Arimoto, R.; Conant, W.C.; Brechtel, F.J.; Bates, T.S.; Cahill, T.A.; Clarke, A.D.; Doherty, S.J.; Flatau, P.J.; et al. ACE-ASIA-Regional climatic and atmospheric chemical effects of Asian dust and pollution. Bull. Am. Meteorol. Soc. 2004, 85, 367-380. [CrossRef]

6. Aldabe, J.; Elustondo, D.; Santamaría, C.; Lasheras, E.; Pandolfi, M.; Alastuey, A.; Querol, X.; Santamaría, J.M. Chemical characterization and source apportionment of $\mathrm{PM}_{2.5}$ and $\mathrm{PM}_{10}$ at rural, urban and traffic sites in Navarra (North of Spain). Atmos. Res. 2011, 102, 191-205. [CrossRef]

7. Guo, H.; Ding, A.J.; So, K.L.; Ayoko, G.; Li, Y.S.; Hung, W.T. Receptor modeling of source apportionment of Hong Kong aerosols and implication of urban and regional contribution. Atmos. Environ. 2009, 43, 1159-1169. [CrossRef]

8. Xu, L.; Chen, X.; Chen, J.; Zhang, F.; He, C.; Du, K.; Wang, Y. Characterization of PM $_{10}$ atmospheric aerosol at urban and urban background sites in Fuzhou city, China. Environ. Sci. Pollut. Res. 2012, 19, 1443-1453. [CrossRef]

9. Watson, J.G.; Zhu, T.; Chow, J.C.; Engelbrecht, J.; Fujita, E.M.; Wilson, W.E. Receptor modeling application framework for particle source apportionment. Chemosphere 2002, 49, 1093-1136. [CrossRef]

10. Wagstrom, K.M.; Pandis, S.N. Source-receptor relationships for fine particulate matter concentrations in the Eastern United States. Atmos. Environ. 2011, 45, 347-356. [CrossRef]

11. Amil, N.; Latif, M.T.; Khan, M.F.; Mohamad, M. Seasonal variability of $\mathrm{PM}_{2.5}$ composition and sources in the Klang Valley urban-industrial environment. Atmos. Chem. Phys. 2016, 16, 5357-5381. [CrossRef]

12. Ho, K.F.; Cao, J.J.; Lee, S.C.; Chan, C.K. Source apportionment of $\mathrm{PM}_{2.5}$ in urban area of Hong Kong. J. Hazard. Mater. 2006, 138, 73-85. [CrossRef] [PubMed]

13. Hopke, P.K.; Gladnet, E.S.; Gordon, G.E.; Zoller, W.H.; Jones, A.G. The use of multivariate analysis to identify sources of selected elements in the Boston aerosol. Atmos. Environ. 1976, 10, 1015-1025. [CrossRef]

14. Uno, I.; Yuminoto, K.; Osada, K.; Wang, Z.; Pan, X. Dust acid uptake analysis during long-lasting dust and pollution episodes over east Asia based on synergetic observation and chemical transport model. SOLA 2017, 13, 109-113. [CrossRef]

15. Lim, Y.K.; Kim, J.; Lee, H.C.; Lee, S.S.; Cha, J.W.; Ryoo, S.B. Aerosol Physical Characteristics over the Yellow Sea During the KORUS-AQ Field Campaign: Observation and Air Quality Model Simulations. Asia-Pacific J. Atmos. Sci. 2019, 55, 629-640. [CrossRef] 
16. Nakajima, T.; Tonna, G.; Rao, R.; Kaufman, Y.; Holben, B. Use of sky-brightness measurements from ground for remote sensing of particulate poly dispersions. Appl. Opt. 1996, 35, 2672-2686. [CrossRef]

17. Sohn, B.J.; Nakajima, T.; Chun, H.W.; Aoki, K. More Absorbing Dust Aerosol Inferred from Sky Radiometer Measurements at Anmyeon, Korea. J. Meteorol. Soc. Jpn. 2007, 85, 815-823. [CrossRef]

18. Lee, J.; Kim, J.; Song, C.H.; Kim, S.B.; Chun, Y.; Sohn, B.J.; Holben, B.N. Characteristics of aerosol types from AERONET sunphotometer measurements. Atmos. Environ. 2010, 44, 3110-3117. [CrossRef]

19. Kim, J.; Lee, J.H.; Lee, H.C.; Higurashi, A.; Takemura, T.; Song, C.H. Consistency of the aerosol type classification from satellite remote sensing during the ABC EAREX campaign. J. Geophys. Res. 2007, 112, D22S33. [CrossRef]

20. Mielonen, T.; Arola, A.; Komppula, M.; Kukkonen, J.; Koskinen, J.; De Leeuw, G.; Lehtinen, K.E.J. Comparison of CALIOP level 2 aerosol subtypes to aerosol types derived from AERONET inversion data. Geophys. Res. Lett. 2009, 36, L18804. [CrossRef]

21. Kchih, H.; Perrino, C.; Cherif, S. Investigation of desert dust contribution to source apportionment of $\mathrm{PM}_{10}$ and $\mathrm{PM}_{2.5}$ from a Southern Mediterranean Coast. Aerosol Air Qual. Res. 2015, 15, 454-464. [CrossRef]

22. Xu, H.; Bi, X.H.; Zheng, W.W.; Wu, J.H.; Feng, Y.C. Particulate matter mass and chemical component concentrations over four Chinese cities along the western Pacific coast. Environ. Sci. Pollut. Res. 2015, 22, 1940-1953. [CrossRef] [PubMed]

23. Rogula-Kozłowska, W.; Klejnowski, K.; Rogula-Kopiec, P.; Ośródka, L.; Krajny, E.; Błaszczak, B.; Mathews, B. Spatial and seasonal variability of the mass concentration and chemical composition of $\mathrm{PM}_{2.5}$ in Poland. Air Qual. Atmos. Health. 2014, 7, 41-58. [CrossRef] [PubMed]

24. Ko, H.J.; Song, J.M.; Cha, J.W.; Kim, J.; Ryoo, S.B.; Kang, C.H. Chemical composition characteristics of atmospheric aerosols in relation to haze, Asian dust and mixed haze-Asian dust episodes at Gosan Site in 2013. J. Kor. Soc. Atmos. Environ. 2016, 32, 289-304. [CrossRef]

25. Seinfeld, J.H.; Pandis, S.N. Atmospheric Chemistry and Physics: From Air Pollution to Climate Change; John Wiley \& Sons, Inc.: New York, NY, USA, 1998.

26. Satsangi, A.; Pachauri, T.; Singla, V.; Lakhani, A.; Maharaj Kumari, K. Water soluble ionic species in atmospheric aerosols: Concentrations and Sources at Agra in the Indo-Gangetic Plain (IGP). Aerosol Air Qual. Res. 2013, 13, 1877-1889. [CrossRef]

27. Harrison, R.M.; Smith, D.T.J.; Luhana, L. Source apportionment of atmospheric polycyclic aromatic hydrocarbons collected from an urban location in Birmingham, UK. Environ. Sci. Technol. 1996, 30, 825-832. [CrossRef]

28. Koçak, M.; Theodosi, C.; Zarmapas, P.; Im, U.; Bougiatioti, A.; Yenigun, O.; Mihalopoulos, N. Particulate matter $\left(\mathrm{PM}_{10}\right)$ in Istanbul: Origin, source areas and potential impact on surrounding regions. Atmos. Environ. 2011, 45, 6891-6900. [CrossRef]

29. Mustaffa, N.I.H.; Latif, M.T.; Ali, M.M.; Khan, M.F. Source apportionment of surfactants in marine aerosols at different locations along the Malacca Straits. Environ. Sci. Pollut. Res. 2014, 21, 6590-6602. [CrossRef]

30. Deshmukh, D.K. Characterization of dicarboxylates inorganic ions in urban $\mathrm{PM}_{10}$ aerosols in the Eastern Central India. Aerosol Air Qual. Res. 2012, 12, 592-607. [CrossRef]

31. Yin, L.; Niu, Z.; Chen, X.; Chen, J.; Zhang, F.; Xu, L. Characteristics of water-soluble inorganic ions in PM $\mathrm{P}_{2.5}$ and $\mathrm{PM}_{2.5-10}$ in the coastal urban agglomeration along the western Taiwan Strait Region, China. Environ. Sci. Pollut. Res. 2014, 21, 5141-5156. [CrossRef]

32. Khamkaew, C.; Chantara, S.; Janta, R.; Pani, S.K.; Prapamontol, T.; Kawichai, S.; Wiriya, W.; Lin, N.H. Investigation of Biomass Burning Chemical Components over Northern Southeast Asia during 7-SEAS/BASELInE 2014 Campaign. Aerosol Air Qual. Res. 2016, 16, 2655-2670. [CrossRef]

33. Meng, C.C.; Wang, L.T.; Zhang, F.F.; Wei, Z.; Ma, S.M.; Ma, X.; Yang, J. Characteristics of concentrations and water-soluble inorganic ions in $\mathrm{PM}_{2.5}$ in Handan City, Hebei province, China. Atmos. Res. 2016, 171, $133-146$. [CrossRef]

34. Gao, Y.; Lee, S.C.; Huang, Y.; Chow, J.C.; Watson, J.G. Chemical characterization and source apportionment of size-resolved particles in Hong Kong sub-urban area. Atmos. Res. 2016, 170, 112-122. [CrossRef]

(C) 2020 by the authors. Licensee MDPI, Basel, Switzerland. This article is an open access article distributed under the terms and conditions of the Creative Commons Attribution (CC BY) license (http://creativecommons.org/licenses/by/4.0/). 